\title{
КОЛДОВСТВО (СИХР) У ТАТАР АСТРАХАНСКОЙ ОБЛАСТИ
}

\begin{abstract}
Статья посвящена изучению традиций колдовства (сихр) у татар Астраханской области. На основании этнографических материалов сделан вывод, что под колдовством у татар понимается, прежде всего, вредоносная магия, порча. Выявлена четкая связь представлений о колдовстве с верованиями в зльх духов. Обнаружены параллели традиций колдовства у нижневолжских татар с аналогичным явлением у других этнотерриториальных групп татар России, в частности, средневолжских, сибирских. Приводимые в статье материалы по этнографии колдовства у татар Астраханской области впервые вводятся в научный оборот.
\end{abstract}

Ключевые слова: Астраханская область, колдовство, магия, порча, сихр, mamapbl

Колдовство, магия (араб. сихр), согласно Корану, - один из больших грехов в исламе $(20: 69 / 72,72 / 75 ; 10: 77 / 78)$. В то же время различного рода магические практики и оккультные знания составляли одну из важнейших сторон культуры всех слоев мусульманского средневекового общества. Астрология играла большую роль в исламском культе и в быту, в русле развития естественных наук важное место занимала алхимия. Практически ни одно из серьезных философских сочинений не обходилось без глав, посвященных магии. Этой теме уделяли внимание и математические сочинения. Гадания и талисманы были и являются характерной чертой мусульманского быта. В качестве последних часто выступают Коран, отдельные суры и айаты. В средневековом суннитском богословии различали два вида магии - «законную» (араб. ат-тарика ал-махмуда - одобряемый путь) и «запретную» (араб. ат-тарика ал-мазмума - порицаемый путь). Считалось, что первая восходит к первочеловеку-пророку Адаму и царю-чародею, повелителю джиннов Сулайману, а вторая - к дьяволу-Иблису. Полагалось, что магия как таковая основана на связи колдуна с духами-джиннами. Люди, практикующие «законную» магию (ал-муаззимун - заклинатели), достигают этой цели посредством подчинения воле Аллаха и обращения к нему за помощью. Те, кто занимается «запретной» магией (ас-сахара - колдуны), связываются с джиннами при помощи злых дел. В мусульманском мире такая практика запрещалась, иногда под страхом смерти (Резван 1991: 211).

Предметом нашей статьи является сихр у татар Астраханской области. Магия была известна тюркам Нижней Волги с давних времен. Анонимный арабский автор XIV в. со слов некоего Бурхан ад-Дина Ибрахима сообщает: «Вот что я видел в

Сызранов Андрей Вячеславович-к.и.н., заведующий кафедрой, Астраханский государственный архитектурно-строительный университет (414056 Астрахань ул. Татищева, 18). Эл.почта: А_ Sizranov@mail.ru Syzranov, Andry V. - PhD. in Hist., Astrakhan State University of Architecture and Civil Engineering (Astrakhan, RF). E-mail: A_Sizranov@mail.ru 
городе Сарае, в степи Кипчацкой, в землях тюрков (имеется в виду г. Сарай - столица Золотой Орды, расположенная в низовьях Волги - А.С.). Случилось, что они (сарайцы) страдали от засухи и что у них не выпадало дождя; вследствие этого они пришли в отчаяние... Вдруг к ним пришла женщина чародейка (курсив наш - А.С.) и сказала им: «Если вы хотите, чтобы к вам пришел дождь, то дайте мне денег». Тогда она уговорилась с жителями города, чтобы они собрали для нее с каждых трех лиц два дирхема и чтобы эти деньги были оставлены у кадия, что если к ним (жителям) придет дождь (вследствие ее чар), то она возьмет деньги, если же нет, то деньги будут возвращены... На другой день все из города отправились за черту его, к тамошней горе, на которой старуха уже успела разбить палатку. Когда время стало подходить к полудню, старуха вышла из палатки: перед нею была одна коза (или козел), с которой была содрана кожа до головы. В руке ее (старухи) находился прут, который она устремляла по направлению к западу. Когда она сделала это, то Аллах всевышний заставил появиться тучу и повелел полить дождю. И задождило по воле Аллаха всевышнего» (Тизенгаузен 1884: 550).

Нельзя точно сказать, имела (или не имела) «женщина чародейка» хоть какое-нибудь отношение к исламу. Однако, успех ее по существу магических действий, естественно, объяснялся автором-мусульманином как проявление Божественной воли. Обряд вызывания дождя (правда, в совсем уже другой, исламизированной форме) бытует в некоторых селах татар, ногайцев, казахов и туркмен Астраханской области. В данном обряде есть элементы имитативной магии, однако к колдовству-сихр, в понимании нижневолжских тюрков, он не имеет никакого отношения.

$\mathrm{B}$ «Летописи о многих мятежах и разорении Московского государства» содержится история о гибели в Астрахани крымского царевича Мурад-Гирея. В 1591 г. некие бусурманские ведуны (судя по тексту, из местных тюрков) в городе испортили царевича. Воеводы привели к нему лекаря-араба. Араб сказал, что царевича нельзя вылечить, пока не сыщут ведунов, которые его портили, пошел с русскими людьми в юрты, схватил там ведунов и принялся их мучить. Ведуны сказали: «Если кровь больного не замерзла, то можно пособить». Тогда араб велел ведунам метать из себя кровь в лохань, и они выметали всю кровь, которую выпили из сонного царевича, его жен и других татар и тем их испортили. Ведуны рассказывали арабу по порядку: вот это - кровь царевича, это - жен, это - других татар. Кровь царевича и одной из его жен замерзла, и ведуны сказали, что им не быть живыми, если же чья-то кровь не замерзла и ею помазать больного, то он останется жив. Мурад-Гирей все-таки умер, воеводы донесли обо всем в Москву, ведунов пытали всячески, но ничего не добились. Лекарь-араб сказал, что такими пытками от ведунов ничего не добиться, и велел вложить им в зубы конские удила, повесить их за руки и бить не по телу, а по стене напротив, и тогда ведуны начали говорить. «А на пытках те Ведуны сказывали, что портили Царевича и цариц и татар, пили из них сонных кровь». После пытки ведунов сожгли, при этом слетелось огромное количество сорок и ворон (Летопись 1788: 18-19; Зайщев 2006: 191).

Ценные сведения о колдовстве-сихр у казанских татар с. Новые Булгары Икрянинского района Астраханской области были собраны местным краеведом Ш.К. Сиражетдиновым. По его материалам, жители села уверены, что колдуны-сихырчи имеют 
дело с жен-пери - злыми духами ${ }^{1}$. Одно упоминание о колдовстве приводит сельчан в крайнее волнение, и всеми порицается. Зловредное искусство колдуна признается всеми реальной угрозой физическому или психическому здоровью человека $(\mathrm{Cu}$ ражетдинов 2008: 191). Зифнуна Фатхуллаева сообщает, что колдуны пускают по ветру заговеренные нити, и человек, случайно их коснувшийся или наступивший на них, может получить головную боль или легкий пралич (Сиражетдинов 2008: 159). По словам Тамары Уразгаливой, колдовство может быть причиной появления у человека беспричинного страха (Сиражетдинов 2008: 184).

В Новых Булгарах жил Абдрахман Баширов (1881 г.р.). Был образованным человеком, учительствовал, давал частные уроки детям сельчан. Славился, как знаток Корана, ворожей-багуче (от татарского багу - смотреть, чыl, че - аффикс, означающий род деятельности) и колдун-сихырчи. Интересно, что сельчане не боялись Абдрахмана и вспоминают о нем с теплотой. Сатира Киреева рассказала, что в 1960-е годы в селе поссорились две соседки. Тогда одна из них решила заколдовать другую и тайком взяла из ее расчески волосы, покрасила их и замотала ниткой. Затем попросила Абдрахмана навести порчу на соседку. Та вскоре сильно заболела и сама, в свою очередь, обратилась к колдуну с просьбой снять с нее порчу. Однако, Абдрахман неожиданно умер. Потерпевшая женщина говорила, что колодовство убило самого колдуна (Сиражетдинов 2008: 192).

Нажия Джумакаева рассказала Ш.К. Сиражетдинову, что у ее отца Хусаина была книга на арабском языке с описаниями магических обрядов. Иногда жители села брали ее на время. Сам Хусаин сихром не занимался, и тогда книгу у него «выпросил Абдрахман Баширов, который умел колдовать» (Сиражетдинов 2008: 193).

По воспоминаням Зифнуны Фатхуллаевой, когда она была меленькой, в Астрахани жила некая Кара Хатима, которая умела наводить порчу. Считалось, что колдунья не может умереть, пока не передаст свой дар преемнику. Кара Хатима передала его своей невестке. «Это черная магия, когда колдунья призывает на помощь нечистую силу. Есть и белая магия. Ее обряды совершаются в помощь человеку». Определить порчу, наведенную колдуном, и снять ее может только багуче, или багуше - ворожей, знахарь, предсказатель по особой книге. Сихырчи способен навести порчу на супругов, например, развести их (Сиражетдинов 2008: 193). Жамал Кудабаева рассказала, как некий Аюп Самитов развелся с первой женой и женился вторично. От второго брака

${ }^{1}$ Образ духа, именуемого джин (или жин, жен), был заимствован тюрками нижней Волги из арабо-мусульманской мифологии. Согласно мусульманской традиции, джинны созданы Аллахом из бездымного огня и представляют собой воздушные или огненные существа, обладающие разумом. Есть джинны-мусульмане, но большинство джиннов составляют воинство Иблиса. Духи жин в представлениях астраханских тюрков близки шайтанам. Они вредят людям, вызывая у них различные болезни и психические расстройства. Астраханские ногайцы-карагаши считают, что если увидишь джинна, то можешь тяжело заболеть. По мнению юртовских ногайских татар, джинны имеют антропоморфный облик, живут под землёй, имеют своих правителей и являются обладателями несметных сокровищ. В юртовских сказаниях герои-батыры сражаются с джиннами и после победы завладевают их сокровищами. Происхождение другого демонического образа - пери связано с иранской мифологией и зороастрийской Авестой. Считается, что пери - это злые духи, имеющие много общего с шайтанами. По представлениям астраханских казахов, пери могут являться в виде животных (например, лошадей) или прекрасных девушек. Они могут так заколдовать человека, что он становится бешенным, психически нездоровым, теряет память. Карагаши считают, что среди пери есть и мужчины и женщины. Пери кружат голову человеку, парализуют его. 
родилось шестеро детей. Однако, Аюп ушел из новой семьи. Выяснилось, что это мать первой жены при помощи некой колдуньи провела обряд дуa салу. Отец Аюпа Абдиш съездил к этой колдунье, которая оказалась его знакомой, но не знала, что Аюп его сын. Снять заклятие она была уже не в силах (Сиражетдинов 2008: 192).

Жительница с. Новые Булгары Гельбану Агисова в 1982 г. развелась с мужем. Вскоре к ней в гости приехала бывшая золовка. Отношения у них были хорошие, и Гельбану тепло встретила ее и обняла. Через полчаса гостья засуетилась и торопливо попрощалась. Гельбану прилегла на кровать и почувствовала себя плохо, правую сторону тела словно парализовало. Когда женщина сняла платье, то обнаружила на плече песок. Одновременно отнялась нога у матери, которая по возвращении домой наступила на рассыпанный песок. Обе женщины обратились за помощью к знахарюбаксы. Он открыл книгу для гаданий и определил, что золовка навела порчу песком, принесенным с могилы. Помимо могильного песка при колдовстве использовали заговоренное пшено (сары ярма), которое рассыпали у порога (Сиражетдинов 2008: 193). Сильнылм колдовским средством также считалась вода, оставшаяся после обмывания покойника и вылитая в яму на кладбище, откуда ее мог взять сихрче для своих целей (Сиражетдинов 2008: 192).

По мнению новобулгаринцев, колдовство-сихр было особо распространено в татарских селах Линейное, Курченко и Туркменка. Это подтверждается и нашими полевыми материалами. Так, по сведениям наших информантов, раньше в с. Линейном Наримановского района Астраханской области были лекари-табибы, которые лечили различные болезни, в том числе изгоняли злых духов из одержимых. СильHblм табибом был Готаулла Таиров (1869-1945). Он лечил людей от одержимости шайтанами. При лечении он применял молитвы, травы. У него был целый сундук старинных книг на арабском языке. Готаулла занимался и колдовством-cblxp - при помощи особой магической книги, страницы которой были исписаны золочеными буквами. В этой книге содержались, в том числе, астрологические знания. Перед смертью Готаулла выкинул ее в реку, опасаясь, что дети и родственники не справятся с колдовством этой книги без него, ведь содержащиеся в ней знания могли быть использованы как для добрых дел, так и для злых. Однажды к лекарю привезли калмыцкого мальчика, одержимого шайтанами. Готаулла лечил его молитвами семь дней. Шайтаны мешали табибу читать молитвы, не давали ему говорить, «вязали» губы. Готаулла говорил, что искусство магического целительства заключается как раз в том, чтобы перебороть шайтанов и дочитать молитву до конца. К нему обращались за помощью и при семейных проблемах. Был известен случай, когда он при помощи магии воссоединил уже разведенных супругов (ПМА).

В с. Курченко Наримановского района Астраханской области до сих пор сохранилась вера и в колдовство, порчу (cblxp). Считается, что колдуны могут навести порчу на кого угодно, и в то же время они могут и вылечить от порчи. Женщин, занимающихся колдовством и гаданием по особой книге, называют багуше. Ранее в с. Линейное жил один колдун, который навел порчу на дочь одного мужчины из рода Сагитовых в с. Курченко. Тогда этот мужчина поехал в Линейное и пригрозил, что убьет колдуна, если он не снимет порчу, что тот под угрозой и сделал. Для спасения от порчи у входа в дом закапывали железные ножницы, вбивали железный гвоздь в косяк двери с правой стороны. Острые железные предметы вообще у тюрков повсеместно считаются эффективным средством против всякой нечистой силы (ПМА). 
В с. Янго-Аскер Наримановского района Астраханской области известна знахарка-багуше Асия Ахмедова, которую односельчане называют Асия-апа (1941 г.р.). Дар знахарства ей передался от матери (в их роду женщины всегда умели лечить). Асия-апа лечит людей от разных болезней. Также она умеет предсказывать будущее, делает любовный приворот и отворот, но, как правило, занимается лечением. За свои услуги берет денежное вознаграждение. Со всей области к ней приезжают люди со своими нуждами. У знахарки есть особая книга, с помощью которой она и лечит. Асия-апа варит снадобья, например, от алкоголизма. По словам жителей села, делать сихр Асия-апа тоже способна, в частности, она может навести порчу (ПМА).

Многие магические приемы использовали шаманы-баксы (Сызранов 2010: 47-55) и муллы, практикующие шаманские и магические методы лечения - так называемые мулла-баксы. В советские времена они вели бродячий образ жизни, перемещаясь от села к селу и предлагая свои услуги - в архивных источниках советского времени их называют бродячее духовенство. Нами была записана история о бродячем мулла-баксы в с. Верхне-Лебяжье Наримановского района Астраханской области. По сообщению Каламсии Рскалиевой, ее мать однажды ночью вышла во двор, и около отхожего места ее ударил шайтан, отчего часть лица у женщины была парализована, и она долго болела. Как-то мимо ехал молодой мулла-баксы. Его лошадь неожиданно встала около дома потерпевшей как вкопанная и отказывалась идти дальше. Мулла-баксы постучался в дом домой и сказал, что видимо здесь кто-то болен, раз его лошадь не идет, и он должен помочь. Осмотрев больную женщину, знахарь велел купить черную курицу. Держа курицу обеими руками, он несколько раз по кругу обнес ее вокруг головы мамы, при этом что-то нашептывая, а затем выкинул курицу на улицу, через забор. После этого мулла-баксы сел на лошадь и отправился дальше, а женщина через некоторое время выздоровела (ПМА).

Сихр был распространен среди разных этнотерриториальных групп российских татар. У татар Среднего Поволжья и Приуралья были известны багучы, сихерче и имче. Багучы - ворожей, гадатель. Сихерче занимался наведением разного рода порчи, приворотов (Воробьев, Хисамутдинов 1967: 364).

Наиболее популярны у татар были имче, или ит-томчь (им - заклинание, том наговор) - заклинатели, колдуны. Имче были преимущественно пожилые женщины, их еще называли имче карчьк (буквально: старуха-заклинатель). С ними часто в народе ассоциировались убырлы-карчык (старуха с убыром - злым духом), в которую, по поверьям, имче-карчык превращается не только после смерти, но и при жизни. В этом, по мнению Г.В. Юсупова, раскрывается шаманское лицо имче, которые сочетали заклинания с чтением мусульманских молитв. О силе воздействия имче в прошлом можно узнать из татарской легенды о чародейке - жене булгарского хана Фатиме, которая волшебством изменила течение Волги (Воробъев, Хисамутдинов 1967: 365).

В селении сибирских татар Большой Карагай Вагайского района Тюменской области и окружающих населенных пунктах до сих пор широко распространены былички о братьях Рахматулле и Хамидулле. Рахматулла был муллой, обучал исламу. Хамидулла был колдун-сихырчи и мог делать всякий сихыр (т.е. колдовство, порчу). Любопытно, что его называли аулийа, т.е. тем же термином, что и захороненных на святых местах сибирских мусульман ( $а с т а н а)$ проповедников. Правда, в данном случае слово аулийа трактовалось как ясновидящий. Хамидулла мог творить разнообразные чудеса: видеть и указать место, где находится пропавшая вещь, раздеть взглядом, одновремен- 
но находиться в нескольких разных местах, внезапно исчезнуть и появиться в другом месте. Односельчане его боялись, и, как рассказывают, в конце концов, он был убит, причем заранее знал время и обстоятельства своей смерти (Селезнев 2009: 20).

Подведём некоторые предварительные итоги. Колдовство, чародейство вообще понимается как занятие различными видами магии. Однако, у татар Астраханской области под колдовством ( $и x p)$ понимается именно вредоносная магия, порча.

Cuxp практиковали колдуны (мужчины и женщины), но часто им занимались и обычные люди. Сихрче были способны как нанести вред своей магией, так и помочь в снятие сглаза, порчи. Повсеместно считалось, что колдуны тесно связаны со злыми духами. Важным атрибутом некоторых колдунов были особые магические книги. Распространены представления, что занятие сихром может навредить как жертве, так и самому колдуну, зеркально ударить по нему.

Один из аспектов рассматриваемой темы - проблема соотношения багуше и сихрче. Здесь возможна подмена понятий в сознании информантов, потому что багуше это, прежде всего, гадалка, сихрче - вредоносный колдун, наводящий порчу. Возможно также, что функции багуше и сихрче иногда могли совмещаться.

Традиции сихра у татар Астраханской области обнаруживают параллели с аналогичным явлением у других этнотерриториальных групп татар, в частности, казанских, мишарских, сибирских.

\section{Источники и материалы}

Летопись 1788 - Летопись о многих мятежах и разорении Московского государства от внутренних и внешних неприятелей. Собрано из древних тех времян описаний. Издание втоpoe. М.: Типография Компании Типографической, 1788.

ПМА - Полевые материалы автора.

Тизенгаузен 1884 - Тизенгаузен В.Г. (сост.) Сборник материалов, относящихся к истории Золотой Орды. Т. 1. Извлечения из сочинений арабских. СПб., 1884.

\section{Научная литература}

Зайцев И.В. Астраханское ханство. 2-е изд. М.: Издательская форма «Восточная литература» PAH, 2006.

Резван Е.А. Сихр // Ислам: Энциклопедический словарь / Милославский Г.В. и др. М.: Главная редакция восточной литературы, 1991.

Селезнев А.Г., Селезнева И.А., Белич И.В. Культ святых в сибирском исламе: специфика универсального. М.: Изд. дом Марджани, 2009.

Сиражетдинов Ш.К. Татарское село Новые Булгары: История. Верования. Фольклор. Икряное, 2008.

Сызранов А.В. Исламизированное шаманство у казахов и ногайцев-карагашей Нижней Волги в XIX - начале XXI в. // Этнографическое обозрение. 2010. № 1. С. 47-55.

Воробьев Н.И., Хисамутдинов Г.М. (отв. ред.). Татары Среднего Поволжья и Приуралья. М.: Издательство «Наука», 1967.

\section{References}

Rezvan, E.A. 1991. Sikhr. In: Islam: Entsiklopedicheskii slovar' [Islam: Encyclopedic Dictionary], edited by G.V. Miloslavsky et al. Moscow: Glavnaia redaktsiia vostochnoi literatury.

Seleznev, A.G., I.A. Selezneva and I.V. Belich 2009. Kul't sviatykh v sibirskom islame: spetsifika universal'nogo [The Cult of Saints in Islam: Specifics of the Universal]. M.: Izd. dom Mardzhani. 
Sirazhetdinov, Sh.K. 2008. Tatarskoe selo Novye Bulgary: Istoriia. Verovaniia. Fol'klor [Tatar Vilage New Bulgary: History. Beliefs. Folklore]. Ikrianoe.

Syzranov, A.V. 2010. Islamizirovannoe shamanstvo u kazakhov i nogaitsev-karagashei Nizhnei Volgi v XIX - nachale XXI v. [Islamized Shamanizm among the Kazakhs and Nogai Karagash People of the Lower Volga in XIX - beginning of XXI s.]. Etnograficheskoe obozrenie 1: 47-55.

Vorobiev, N.I., and G.M. Khisamutdinov (eds.). 1967 Tatary Srednego Povolzh 'ia i Priural'ia [Tatars of the Middle Volga Region and the Urals]. Moscow: Izdatel'stvo "Nauka".

Zaitsev, I.V. 2006. Astrakhanskoe khanstvo [Astrakhan Khanate]. 2-e izd. Moscow: Izdatel'skaia forma "Vostochnaia literature" RAN.

Syzranov, Andrey $V$.

\section{Witchcraft (Sikhr) among the Tatars of Astrakhan Region}

The article is devoted to the study of traditions of witchcraft (sihr) among the Tatars of the Astrakhan region. Based on ethnographic materials, it was concluded that witchcraft among the Tatars is mainly associated with harmful magic and spells. The study reveals a clear connection between ideas about witchcraft and beliefs in evil spirits. It was found that the traditions of witchcraft among the Lower Volga Tatars are parallel to similar phenomena among other ethnoterritorial groups of Tatars in Russia, in particular, the Middle Volga and Siberian Tatars. The materials on the ethnography of witchcraft among the Tatars of the Astrakhan region are being published for the first time.

Keywords: Astrakhan region, witchcraft, magic, spells, sihr, Tatars 